\title{
Effect of Kaulitika Varti-Madhu Ashchyotana in the Management of Kaphaja Abhishyanda with Special Reference to Vernal Keratoconjunctivitis (VKC) - A Case Study
}

\author{
Raju Kumar ${ }^{1}$, Prabhakar Vardhan², Gulab Chand Pamnani ${ }^{3}$, \\ Rajendra Kumar Soni ${ }^{4}$
}

${ }^{1}$ PG Scholar, PG Department of Shalakya Tantra, National Institute of Ayurveda, Jaipur, Rajasthan, India

${ }^{2}$ Assistant Professor, PG Department of Shalakya Tantra, National Institute of Ayurveda, Jaipur, Rajasthan, India

${ }^{3}$ Associate Professor, PG Department of Shalakya Tantra, National Institute of Ayurveda, Jaipur, Rajasthan, India

${ }^{4}$ Lecturer, Shalakya Tantra Department, National Institute of Ayurveda, Jaipur, Rajasthan, India

Corresponding Author: Raju Kumar

\begin{abstract}
Rationale: Vernal Keratoconjunctivitis (VKC) is a recurrent bilateral chronic allergic inflammatory disease of the ocular surface affecting mainly young children in first decade of life. As per Ayurveda, the disease VKC bears resemblance to the kaphaja abhishyanda which is one among four types of abhishyanda (conjunctivitis). The line of treatment of abhishyanda is langhana (fasting), lepana (anointing with medicated paste), swedana (causing perspiration), siravedhana (venesection), virechana (purgation), anjana (collyria application) and ashchyotana (guttae application) respectively. Based on this principle, the present case was managed with amapachanayoga and ashchyotana as per classical guidelines.

Background: An Indian female aged 23 years presented in December 2020 with complaints of severe itching, watering, redness, papillae on upper palpebral conjunctiva, gelatinous opacification (approx. $2 \mathrm{~mm}$ in size) around the limbus and Tranta's dots for 11 years. The patient had recurrent episodes of this illness since last 11 years.

Intervention and Outcome: The patient was treated on prescribed line of treatment i.e. langhana (amapachana) and ashchyotana as described in Ayurveda for abhishyanda disease. Before treatment, the severity score determined by the 5-5-5 Exacerbation Grading Scale in VKC was 145. After the therapy, the severity score reduced to 0.00 . Hence, $100 \%$ improvement in disease severity.
\end{abstract}

Keywords: abhishyanda, ashcyotana, amapachana, spring catarrah

\section{INTRODUCTION}

VKC is a recurrent bilateral chronic allergic inflammatory disease of the ocular surface affecting mainly young children in first decade of life. ${ }^{1}$ The prevalence of allergic ocular disease was $20.1 \%$ and VKC described $3.9 \%$ of ocular allergies in children. ${ }^{2}$ Allergies tend to run in families, although no obvious mode of inheritance is identified. Therapies imparted by modern science include lubricants, decongestants, mast cell stabilizer, antihistamines, topical steroids, NSAIDs and immune-modulators eye drops. Antihistamines are suitable for short term use (2-6 weeks), but do not prevent future recurrence of symptoms. Cataract, glaucoma, infections and corneal melting may occur with treatment with 
Raju Kumar et.al. Effect of kaulitika varti-madhu ashchyotana in the management of kaphaja abhishyanda with special reference to vernal keratoconjunctivitis (VKC) - a case study.

topical steroids. In Ayurveda, the features of vernal keratoconjuctivitis very well resemble to features of kaphaja abhishyanda- a subtype of four types of abhishyanda (conjunctivitis). The line of treatment of abhishyanda is langhana, lepana, swedana, siravedhana, virechana, anjana and ashcyotana depending on the presentations of the disease. Based on this treatment principle, the present case was managed with amapachana yoga ${ }^{3}$ and ashchyotana ${ }^{4}$. There was marked improvement in symptoms and signs of the disease with this simple treatment regimen. The present case emphasizes that the Ayurveda has tremendous potential in dealing with such chronic and distressing illnesses.

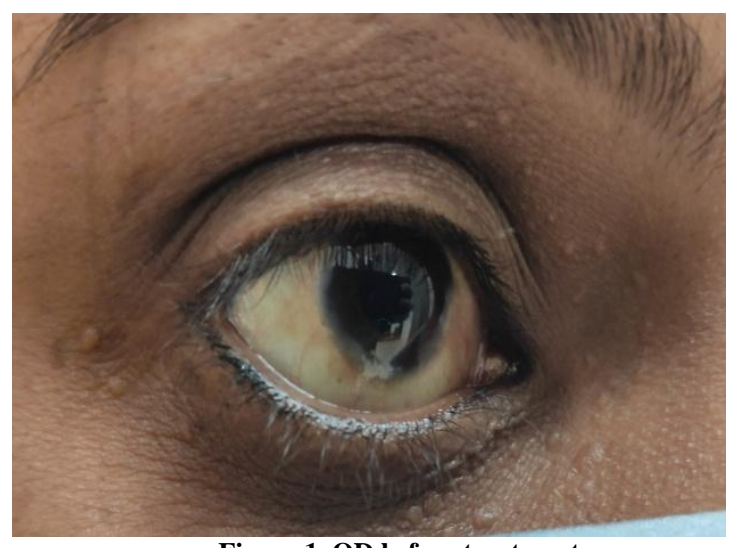

Figure 1. OD before treatment

\section{Diagnostic evaluation and Assessment}

On visual acuity examination, it was found that vision in right and left eyes were 6/6 partial in both eyes correctable up to $6 / 6$. On slit lamp examination there were numerous papillae present on upper palpebral conjunctiva, gelatinous opacification around the limbus $(2 \mathrm{~mm}$ in size) and Tranta's dots.

\begin{tabular}{|c|c|c|}
\hline & OD(Right eye) & OS(Left eye) \\
\hline Eyelashes & Normal & Normal \\
\hline Eyelids & Normal & Normal \\
\hline Conjunctiva & $\begin{array}{l}\text { Congestion, papillae } \\
\text { present on upper } \\
\text { palpebral conjunctiva }\end{array}$ & $\begin{array}{l}\text { Congestion, papillae } \\
\text { present on upper } \\
\text { palpebral conjunctiva }\end{array}$ \\
\hline Cornea & $\begin{array}{l}\text { Gelatinous } \\
\text { opacification, Tranta's } \\
\text { dots }\end{array}$ & $\begin{array}{l}\text { Gelatinous } \\
\text { opacification, Tranta's } \\
\text { dots }\end{array}$ \\
\hline Pupil & $\begin{array}{l}\text { Shape \& Size- Normal, } \\
\text { Reaction- Normal }\end{array}$ & $\begin{array}{l}\text { Shape \& Size- Normal, } \\
\text { Reaction- Normal }\end{array}$ \\
\hline Lens & Clear & Clear \\
\hline
\end{tabular}

\section{CASE REPORT}

An Indian female of age 23 years and weight $55 \mathrm{~kg}$ came to Netraroga OPD of National institute of Ayurveda, Jaipur, with complaints of excessive itching, watering, redness, papillae on upper palpebral conjunctiva, gelatinous opacification (approx. $2 \mathrm{~mm}$ in size) around the limbus and Tranta's dots for 11 years. The patient had recurrent episodes of this illness since last 11 years. Earlier these exacerbations were contained satisfactorily with lubricants, mast cell stabilizer, antihistamines and topical steroid eye drops, by which she was getting symptomatic relief. The patient has no significant family history. She is a nurse by profession and her work was impacted by her ailment.

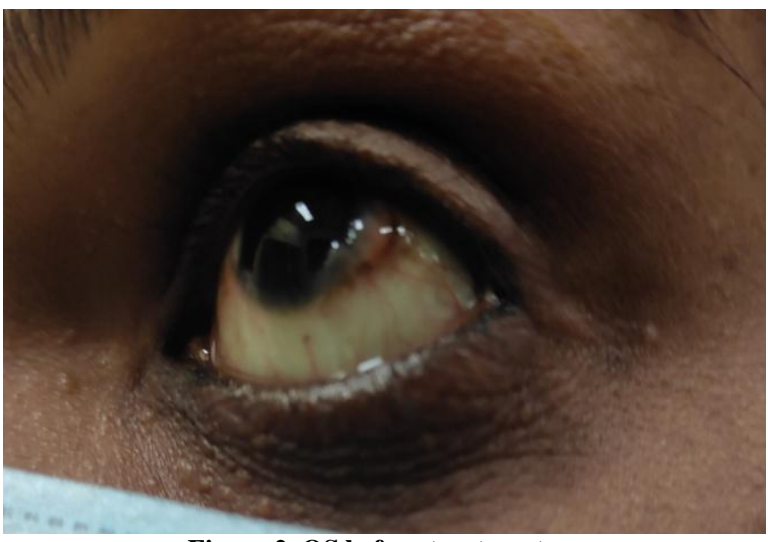

Figure 2. OS before treatment

Her blood investigation done on 22/03/2020 showed ESR- $8 \mathrm{~mm} / \mathrm{Hr}$,T.E.C.$0.19, \mathrm{Hb}-14.4 \mathrm{~g} / \mathrm{dl}$, TLC- 6.6, TEC-4.9, PLT-224.0, HCT- 44.5\%, M.C.V.- 90.6fL, MPV- 11fl, M.C.H.- 29.3pg, M.C.H.C.32.3gm/dl, R.D.W.CV- $11.6 \%$, N 54.2\%, L $35.4 \%$, M $6.6 \%$, E $2.8 \%$, B $0.8 \%$, ANC3.6, ALC- 2.34, AMC- 0.44, AEC- 0.18, ABC- 0.05 , FBS- $91.2 \mathrm{mg} / \mathrm{dl}$. Her blood pressure was $120 / 80 \mathrm{~mm}$ of $\mathrm{Hg}$, Height5.2 feet, weight61 kg.

On the basis of signs and symptoms the present case was diagnosed as a case of kaphaja abhishyanda as per explained in the classical texts ${ }^{5}$ and on the basis of history and slit lamp examination it was categorized as Vernal Keratoconjunctivitis (VKC) ${ }^{6}$. Her severity score determined by the $5-5-5$ 


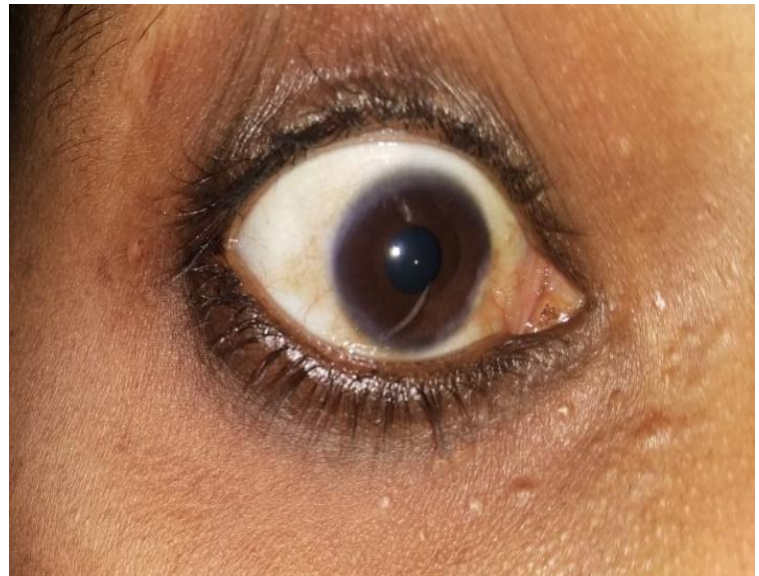

Figure 3. OD after treatment

\section{DISCUSSION}

In the present case study, patient was given Kaulitika Varti Ashchyotana after aamapachana. The diagnosis was done on the basis of signs and symptoms described in ayurvedic and modern texts and then examined on clinical parameters. During the treatment, patient was assessed on every $8^{\text {th }}$ day of treatment. Hence patient was examined four times during total period of therapy. After one month, drug administration was stopped and patient was followed up for further one month. During and after the course of therapy, there were no side effects of the treatment. There was relief in the various symptoms of Kaphaja abhishyanda (vernal keratoconjunctivitis) like redness, foreign body sensation,

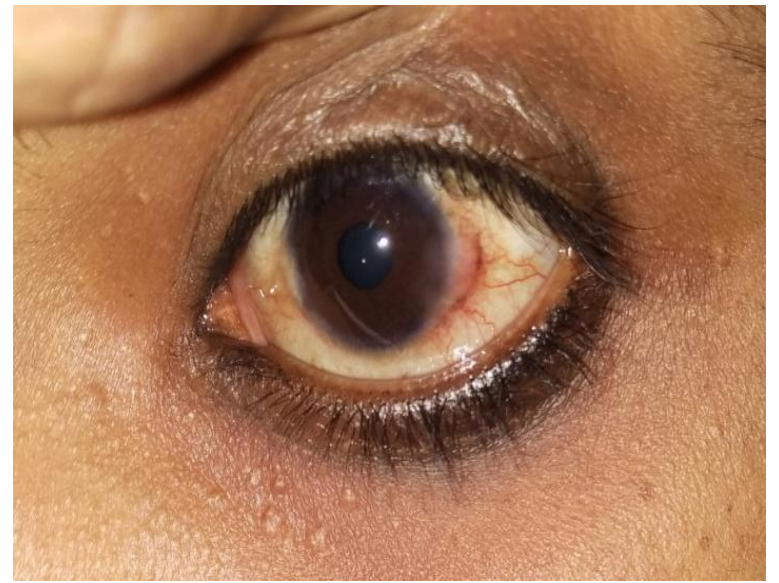

Figure 4. OS after treatment

burning sensation etc. This treatment decreased the various signs of Kaphaja abhishyanda (vernal keratoconjunctivitis) like conjunctival congestion and gelatinous opacification also.

The physiological effects of the drugs and mechanism of their action are best understood by the properties of its basic physiochemical factors i.e. Rasa, Guna, Veerya, Vipaka, Karma, and Prabhava of the drugs. These primarily affect the Doshas and determine their Doshakarma activity, which in turn corrects the vitiated Doshas and maintains the Doshika equilibrium of the body. The Pharmaco-dynamics of the selected drugs of the present study can be explained as follows:

Table no. 5: Pharmaco-Dynamics of Aampachana Drugs (Rasa Panchaka)

\begin{tabular}{|c|c|c|c|c|c|c|c|}
\hline \multirow[t]{2}{*}{ Drug } & \multicolumn{4}{|l|}{ Pharmacological properties } & \multicolumn{3}{|c|}{ Therapeutic properties } \\
\hline & Rasa & Guna & Virya & Vipaka & Vata & $\overrightarrow{\text { Pitta }}$ & Kapha \\
\hline Dhanyaka $^{i}$ & Kashaya, Tikta, Madhura, Katu & Laghu, Snigdha & Ushna & Madhura & & & \\
\hline Mustaka ${ }^{\ddot{i}}$ & Tikta, Katu, Kashaya & Laghu, Ruksha & Sheeta & Katu & & 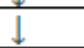 & $\downarrow$ \\
\hline Shunthi & Katu & Laghu & Ushna & Madhura & $\downarrow$ & $\downarrow$ & \\
\hline
\end{tabular}

The Aampachana drug has a predominance of Katu, Tikta, Kashaya Rasa, Laghu, Ruksha Guna Ushna Veerya, Madhura Vipaka. Considering the Doshakarma is Kapha-Pitta-vatashamaka (Tridoshashamaka) by its Rasa, Guna, Veerya, and Vipaka. Thus, the overall effect of the compound drug is Aampachana and hence it disintegrates the pathology of the disease Kaphaja Abhishyanda, which is Kapha-Pittaja in its manifestation.
Pharmacological properties of contents of Aampachana yoga:

- Dhanyaka (Coriander sativum) is having Anti-inflammatory, analgesic, antioxidant, antimicrobial, anti-bacterial, anti-fungal, Hepato-protective activity, anticancer, hypolipidemic, hypoglycemic, gastrointestinal effects. ${ }^{11}$

hypotensive

- Mustaka (Cyperus rotundus) is having anti-inflammatory, anti-allergic, anti- 
histamine, analgesic, antiulcer, antiarthritic, antioxidant, anti-platelet, antipyretic, anti-viral, anti-candida, antimalaria, anti-helminthic and wound healing activity. ${ }^{12}$

- Sunthi (Zingiber officinalis) is having anti-inflammatory, analgesic, antiallergic, antimicrobial, antioxidant, hepato-protective, immune-modulatory and antacid activity. ${ }^{13}$

\section{Method of preparation of Kaulitika- vartiashcyotana $^{14}$ :}

Daruharidra, Aja-dugdha and Madhu was processed to prepare Kaulitika Varti Ashcyotana, a topical ophthalmic medication mentioned in Gadnigraha (Netra Rogadhikara).

- Daruharidra was taken as a yavkutachurna (coarse powder) and kwatha (decoction) was prepared by adding 16 times water, heated and reduced the volume to one fourth, after then filtered with a muslin cloth. Ajadugdha (goat's milk) was taken in a ration of $1 / 8$ part to Daruharidra in a stainless-steel vessel and heated on low flames and then mixed it into filtered decoction and paka was done in mandagni. It was then thoroughly stirred while adding Aja-dugdha and it was heated with constant stirring maintaining the temperature till it attained Raskriya (ointment like) form. Heating was stopped when Varti was formed. Varti was tested for the absence of crackling sound.

- Kaulitika Varti Ashcyotana was prepared by mixing Varti with honey and the product was packed into a $10 \mathrm{ml}$ sterile bottle. It was used in the form of ashcyotana topically for 30 days.

Table no 6: Pharmaco-Dynamics of KaulitikaVartiAshcyotana

\begin{tabular}{|l|l|l|l|l|l|l|l|}
\hline \multirow{2}{*}{ Drug } & Pharmacological properties & \multicolumn{2}{|l|}{ Therapeutic properties } \\
\cline { 2 - 7 } & Rasa & Guna & Virya & Vipaka & Vata & Pitta & Kapha \\
\hline Daruharidra $^{\text {v }}$ & $\begin{array}{l}\text { Tikta, Kashaya } \\
\text { (Rasanjana-katu) }\end{array}$ & Laghu, Ruksha & Ushna & Katu & & $\downarrow$ & $\downarrow$ \\
\hline Aja-dugdha $^{v}$ & Madhura & Guru, Snigdha, Mridu, Pichchila & Sheeta & Madhura & $\downarrow$ & $\downarrow$ & \\
\hline Honey $^{\text {v }}$ & Madhura, Kashaya & Laghu, Ruksha, Shlakshana, Vishada & Sheeta & Madhura & $\downarrow$ & $\downarrow$ & \\
\hline
\end{tabular}

The drug kaulitika varti ashchyotana has a predominance of kashaya, madhura, tiktarasa, laghu, ruksha, mridu, shlakshana, vishada guna sheeta veerya, madhura vipaka. Considering the doshakarma, the drug is vata-pitta-kaphashamaka by its rasa, guna, veerya, and vipaka. Thus, the overall effect of the compound drug is vatapitta-kaphashamaka and hence it disintegrates the pathology of the disease kaphaja abhishyanda, which is kaphapittaja in its manifestation.

\section{Pharmacological properties of contents of Kaulitikavarti:}

- Daruharidra (Berberis aristata) extract (berbarine, berberine, oxycanthine, epiberberine, dehydrocaroline, palmatine, columbamine etc.) shows anti allergic activity, anti-inflammatory. It is also reported as an antioxidant activity, antimicrobial, antioxidant, anticancer, wound healing, eye and ear infections, jaundice, skin diseases. ${ }^{18}$

- Aja-dugdha (Lactus) is having antiinflammatory and anti-allergic activity.

- Honey is having anti-inflammatory, antioxidant, antimicrobial, antibacterial activity, anti-fungal, antiviral, wound healing. ${ }^{20}$

\section{CONCLUSION}

Kaulitika varti-madhu ashcyotana was found to be very effective in relieving all the clinical features like itching, watery discharge, redness, foreign body sensation, burning sensation, palpebral \& bulbar conjunctival congestion and gelatinous 
Raju Kumar et.al. Effect of kaulitika varti-madhu ashchyotana in the management of kaphaja abhishyanda with special reference to vernal keratoconjunctivitis (VKC) - a case study.

opacification. The treatment was devoid of any toxic effect also and thus can safely substitute the modern management of vernal keratoconjunctivitis

Abhishyanda).

(Kaphaja

PATIENT PERSPECTIVE: I had attained marked relief in this disease which I couldn't get for so many years. I am very much satisfied and thankful for bringing me to this stage of almost being normal for which I was aspiring since long time.

INFORMED CONSENT: An informed written consent was obtained from the patient before reporting her case.

\section{ACKNOWLEDGEMENT}

The present case study has been prepared keeping in view the CARE GUIDELINE.

\section{Conflict of Interest: None}

\section{Source of Funding: None}

\section{REFERENCES}

1. KanskiJ. Jack Bowling Bard, clinical ophthalmology- A Systemic Approach, $8^{\text {th }}$ ed; Elsevier: International edition, 2016; Chapter 5. pg. 145.

2. Ahmed, SamahM.M \& Ahmed, Khaled \& Morsy, OsamaA \& Soliman, Shaimaa. (2019). Epidemiology of Vernal Keratoconjunctivitis (VKC) among children aged (12-15) years - Menofia Governorate, Egypt. Delta Journal of Ophthalmology. 20. 1. 10.4103/DJO.DJO_42_18.

3. Agnivesh. Charak Samhita. Reprient Edition. Kashinatha Shastri, Gorakhanatha Chaturvedi, Commentator. Varanasi: Chaukhambha Sanskrit Sansthana; 2011. Chikitisa Sthan, Adhyaya 19, Verse 20.

4. Sushruta. Sushruta Samhita. Reprint Edition. Ambika Dutta Shastri, Commentator. Varanasi: Chaukhambha Sanskrit Sansthana; 2015. Uttar Tantra, Adhyaya 6, Verse 5.

5. Sushruta. Sushruta Samhita. Reprint Edition. Ambika Dutta Shastri, Commentator. Varanasi: Chaukhambha
Sanskrit Sansthana; 2015. Uttar Tantra, Adhyaya 6, Verse 8.

6. Samar K. Basak, Essentials of ophthalmology, $5^{\text {th }}$ edition, Current book International, Kolkata, 2005. Pg-151.

7. Shoji J, Inada N, Sawa M. Evaluation of novel scoring system named 5-5-5 exacerbation grading scale for allergic conjunctivitis disease. Allergol Int. 2009 Dec;58(4):591-7. doi: 10.2332/allergolint.09-OA-0100. Epub 2009 Sep 25. PMID: 19776677.

8. P. V. Sharma, Dravya guna Vijnana, Varanasi: Chaukhambha Bharti Academy, Vol. IInd Pg.- 323.

9. P. V. Sharma, Dravya Guna Vijnana, Varanasi: Chaukhambha Bharti Academy, Vol. IInd Pg.- 370.

10. P. V. Sharma, Dravyaguna Vijnana, Varanasi: Chaukhambha Bharti Academy, Vol. IInd Pg.- 331.

11. Prachayasittikul V, Prachayasittikul S, Ruchirawat S, Prachayasittikul V, Coriander (Coriandrum Sativum): A Promising Functional Food Toward the Well-Being Food Res Int. 2018 Mar;105:305-323. doi:

10.1016/j.foodres.2017.11.019. Epub 2017 Nov 21.

12. Kamala A, Middha SK, Karigar CS, Plants in Traditional Medicine With Special Reference to Cyperus rotundus $\mathrm{L}$. Pharmacogn Mag. 2018 Jul;8(7):309. doi: 10.1007/s13205-018-1328-6. Epub 2018 Jul 9.

13. Justo OR, Simioni PU, Gabriel DL, Tamashiro WMDSC, Rosa PDTV, Moraes AM, Evaluation of in Vitro AntiInflammatory Effects of Crude Ginger and Rosemary Extracts Obtained Through Supercritical $\mathrm{CO} 2$ Extraction on Macrophage and Tumor Cell Line: The Influence of Vehicle TypeBMC Complement Altern Med. 2015 Oct 29;15:390.doi: 10.1186/s12906-015-0896-9.

14. Vaidya Sodhala. Gadanigraha. Fist Edition. Indradev tripathi, Hindi Commentater. Varanasi: Chaukhambha Prakashana; 1969. Part-III Netrarogadhikara, Abhishyanda chikitisadhyaya Verse 272275.

15. P. V. Sharma, Dravyaguna Vijnana, Varanasi: Chaukhambha Bharti Academy, Vol. IInd Pg.- 537. 
Raju Kumar et.al. Effect of kaulitika varti-madhu ashchyotana in the management of kaphaja abhishyanda with special reference to vernal keratoconjunctivitis (VKC) - a case study.

16. P. V. Sharma, Dravyaguna Vijnana, Varanasi: Chaukhambha Bharti Academy, Vol. IIInd Pg.- 297

17. P. V. Sharma, Dravyaguna Vijnana, Varanasi: Chaukhambha Bharti Academy, Vol. IIInd Pg.- 291.

18. Potdar D, Hirwani RR, Dhulap S, Phytochemical and Pharmacological Applications of Berberis Aristata Fitoterapia. 2012 Jul;83(5):817-30.doi: 10.1016/j.fitote.2012.04.012

19. Jirillo F, Magrone T, Anti-inflammatory and Anti-Allergic Properties of Donkey's and Goat's Milk Endocr Metab Immune Disord Drug Targets. 2014 Mar;14(1):27-37.doi: 10.2174/1871530314666140121143747.

20. Biluca FC, Silva BD, Caon T, Mohar ETB, Vieira GN, Gonzaga LV et.al.
Investigation of Phenolic Compounds, Antioxidant and Anti-Inflammatory Activities in Stingless Bee Honey (Meliponinae) Food Res Int. 2020 Mar;129:108756. doi:

10.1016/j.foodres.2019.108756. Epub 2019 Nov 27.

How to cite this article: Kumar R, Vardhan P, Pamnani GC et.al. Effect of kaulitika vartimadhu ashchyotana in the management of kaphaja abhishyanda with special reference to vernal keratoconjunctivitis (VKC) - a case study. Int J Health Sci Res. 2021; 11(5): 229235. DOI: https://doi.org/10.52403/ijhsr. 20210537 